\title{
ANALISIS EKONOMI USAHA SAPI POTONG DI LAHAN PERKEBUNAN SAWIT DAN KARET
}

\author{
S.Rusdiana, R. Hutasoit dan J. Sirait \\ Balai Penelitian Ternak Ciawi-Bogor Jawa Barat \\ Loka Penelitan Kambing Potong Sei Putih Medan No.1 Galang-Sumatera Utara \\ E-mail: s.rusdiana20@ gimail.com
}

\begin{abstract}
The study was conducted in the village of Pulo Bandring Tanah Rakyat District of Asahan in North Sumatra Province. The study was conducted in 2015 using the method of field survey on 30 respondent beef cattle farmers in a way purposive random sampling. The primary data obtained through interviews directly in the field with farmers beef cattle, which refers to the questionnaire has been prepared, while secondary data obtained from the Extension Service, Plantation, Agriculture and Livestock local, then the data collected was processed and tabulated descriptive, quantitative and economic analysis. The purpose of this paper is to determine the economic analysis in the beef cattle business in a manner shepherd breeder dilahan palm and rubber plantations in Asahan. The results showed that the net income of the business of cattle by means of grazing dilahan oil palm and rubber plantations around Rp.3.185.000/breeder/year with B/C ratio of 1.2. Labor breeder beef cattle by about 20,000 working time/day 8 hours is calculated based on the first working Hok / day. For the breeders of beef cattle in the Village People's District of Pulobandring Asahan immediately in the push towards commercial business, so that the cattle were reared by farmers to grow, can produce well, and pertamabahan body weight increases, so that the sale value of cattle higher in terms of the market price of cattle.
\end{abstract}

Keywords: business, cattle, plantations, grazing

\begin{abstract}
Abstrak : Penelitian dilakukan di Desa Tanah Rakyat Kecamatan Pulobandring Kabupaten Asahan Provinsi Sumatera Utara. Penelitian dilakukan pada tahun 2015 dengan menggunakan metoda survey lapang terhadap 30 responden peternak sapi potong dengan cara purposive sampling random. Data primer diperoleh melalui hasil wawancara langsung di lapangan dengan peternak sapi potong yang mengacu kepada kuisioner yang telah disiapkan, sedangkan data sekunder diperoleh dari Dinas Penyuluhan, Perkebunan, Pertanian dan Peternakan di lahan setempat, kemudian data yang terkumpul diolah dan ditabulasi secara deskriptif, kuantitatif dan analisis ekonomi. Tujuan tulisan ini adalah untuk mengetahui analisis ekonomi usaha sapi potong di peternak dengan cara digembalakan di lahan perkebunan sawit dan karet di Kabupaten Asahan. Hasil penelitian menunjukkan bahwa, pendapatan bersih dari usaha ternak sapi potong dengan cara digembalakan di lahan perkebunan kelapa sawit dan perkebunan karet sekitar Rp.3.185.000/peternak/tahun dengan B/C ratio 1.2. Upah tenaga kerja peternak sapi potong berdasarkan waktu kerja sekitar Rp.20.000/hari waktu 8 jam dihitung berdasarkan 1 Hok kerja/hari. Untuk itu peternak sapi potong di Desa Tanah Rakyat Kecamatan Pulobandring Kabupaten Asahan segera didorong ke arah usaha yang bersifat komersial, agar ternak sapi potong yang dipelihara oleh peternak bertambah, dapat berproduksi dengan baik, dan pertambahan bobot badan meningkat, sehingga nilai jual ternak sapi potong lebih tinggi dari segi harga pasar ternak.
\end{abstract}

Kata kunci: usaha, sapi potong, perkebunan, penggembalaan 


\section{PENDAHULUAN}

Kesejahteraan petani merupakan tujuan utama untuk pembangunan pertanian, sektor pertanian dan peternakan sangat besar kontribusinya, terutama dalam peningkatan perekonomian masyarakat. Usaha ternak sapi potong merupakan komponen yang sangat penting dalam usahatani ternak di pedesaan, karena pemeliharaan ternak sapi potong dengan skala kecil dapat membantu perekonomian peternak. Disamping itu sapi potong juga merupakan salah satu satu komoditas yang banyak dipelihara oleh peternak kecil di Desa Tanah Rakyat, dan sebagai fungsi pendapatan utama, tabungan untuk kebutuhan anak sekolah dan lainnya. Mengingat sifat dan reproduksi sapi potong sangat lama sekitar satu tahun, tetapi peternak tetap melakukan usahanya dengan baik, kesempatan peternak untuk menjualnya setahun sekali.

Usaha ternak sapi potong merupakan salah satu sumber pertumbuhan baru dalam menunjang pendapatan peternak, disamping usaha pertanian dan lainnya. Perkembangan populasi ternak sapi potong di Indonesia sejak tahun 2009 hingga tahun 2014 mengalami kenaikan yang cukup baik sebesar 1.943 .000 ekor atau sekitar $15,22 \%$, dimana populasi pada tahun 2009 sebesar 12.760 .000 ekor menjadi sebesar 14.703.000 ekor pada tahun 2014, jika diperhitungkan secara rataan per tahun maka kenaikannya sekitar 3,12\%/tahun, (Dirjen Peternakan dan Kesehatan Hewan, 2013) dan populasi sapi potong di Kabupaten Asahan sekitar 28.378 ribu ekor, (Dinas Perkebunan, Pertanian dan Peternakan Kabupaten Asahan 2013). Sedangkan Menurut Haddi et al. (2011) bahwa, dampak dari kemajuan pertumbuhan ekonomi di Indonesia dengan kebutuhan asal daging ternak sapi potong akan semakin meningkat setiap tahunnya.

Tantangan yang sering dihadapi untuk usaha ternak sapi potong adalah kemampuan untuk memenuhi kebutuhan ekonomi peternak setiap hari, sehingga melalui perbaikan produksi dan kualitas ternak sapi potong perlu pembinaan kepada petani yang daerahnya potensial. Ketersediaan lahan perkebunan kelapa sawit, perkebunan karet, lahan pertanian, lahan kosong, tegalan, sawah dan ladang, merupakan lahan yang potensial untuk menyediakan hijauan pakan ternak, baik rumput atau berbagai limbah pertanian, dapat dimanfaatkan sebagai pakan ternak sapi potong, (Kusnadi et al.2006). Pengembangan usaha ternak sapi potong dipandang sangat cocok dalam kondisi lahan perkebunan kelapa sawit dan karet, karena ternak sapi potong dikenal mudah beradaptasi pada berbagai kondisi lingkungan agroekosistem lahan perkebunan dan pertanian, merupakan usaha komplementer.

Pengembangan sumber daya manusia merupakan proses untuk meningkatkan pengetahuan, kreativitas dan keterampilan, serta kemampuan dalam berusaha tani, (Demitria et al. 2006). Secara biologis ternak sapi potong cukup produktif dan adaptif dengan kondisi lingkungan perkebunan kelapa sawit dan perkebunan karet, sehingga mudah cara pengembangannya. Pengembangan sapi potong dapat lebih diarahkan ke luar Jawa mengingat besarnya sumberdaya alam di daerah-daerah cukup potensial salah satunya di Desa Tanah Rakyat Kecamatan Pulobandring Kabupaten Asahan. Lahan kosong perkebunan kelapa sawit, karet, kelapa dan tegalan merupakan sumber pakan ternak, seperti rumput gajah, rumput bracilia, gliricia, lamtoro, kaliandra, rumput sawah, rumput raja, rumput lapangan, rumput raket, rumput jampang, dan sisa limbah hasil pertanian.

Lahan perkebunan kelapa sawit, perkebunan karet, pertanian dan peternakan sebagai wilayah

Provins Sumatera Utara, sampai saat ini masih menjadi mata pencaharian yang dominan bagi masyarakat di Kecamatan Pulobandring Kabupaten Asahan, meskipun demikian, bukan berarti pendapatan petani hanya mengandalkan dari usaha buruh perkebunan, dagang dan usaha tanaman pangan lainnya, tetapi dari hasil usaha ternak sapi potong juga ikut andil dalam menunjang kesejahteraan peternak. Berdasarkan permasalahan tersebut di atas, maka perlu dilakukan penelitian mengenai pendapatan usaha ternak sapi potong di peternak, disamping usaha buruh perkebunan dan lainnya. Tujuan tulisan ini adalah untuk menganalisis ekonomi usaha sapi potong di peternak dengan cara digembalakan di lahan perkebunan sawit dan karet. 


\section{METODOLOGI}

\section{Waktu dan Tempat Penelitian}

Penelitian dilakukan di Desa Tanah Rakyat Kecamatan Pulobandring Kabupaten Asahan Propinsi Sumatera Utara, pemilihan lokasi penelitian dilakukan sesuai dengan kriteria luas lahan perkebunan kelapa sawit, luas lahan perkebunan karet, pertanian dan lahan kosong yang belum tergarap baik oleh petani maupun pihak dari perkebunan, serta populasi ternak sapi potong. Penelitian dilakukan pada tahun 2015, dengan menggunakan survey lapang terhadap 30 responden peternak sapi potong, dengan cara purposive sampling random.

\section{Analisis Data}

Data primer diperoleh melalui hasil wawancara langsung di lapangan dengan responden, mengacu kepada kuisioner yang telah disiapkan, sedangkan data sekunder diperoleh dari Dinas Penyuluh Pertanian dan Peternakan setempat, data yang dikumpulkan dari hasil penelitian survey lapang diolah, kemudian ditabulasi secara deskriptif, kuantitatif dan analisis ekonomi B/C, (Atmakusuma et al. 2014), dengan rumus:

Rumus: $\mathrm{Y}=\mathrm{P}+\mathrm{Q}-\mathrm{M}-\mathrm{N}-\mathrm{O}$

Keterangan:

$\mathrm{Y}=$ pendapatan bersih dari ternak sapi potong

(Rp/tahun)

$\mathrm{P}=$ nilai ternak sapi potong pada akhir tahun

(Rp/tahun)

$\mathrm{Q}=$ nilai ternak sapi potong yang dijual selama satu tahun (Rp/tahun)

$\mathrm{M}=$ nilai ternak sapi potong pada awal tahun

(Rp/tahun)

$\mathrm{N}=$ nilai ternak sapi potong yang dibeli selama satu tahun (Rp/tahun)

$\mathrm{O}=$ biaya pemeliharaan ternak sapi potong selama satu tahun (Rp/tahun)

Rumus: $\mathrm{O}=\mathrm{TFC}+\mathrm{TVC}$

Keterangan:

$\mathrm{O}$ = biaya pemeliharaan sapi potong selama satu tahun (Rp/tahun)

TFC $=$ Total biaya tetap (Rp/tahun)

$\mathrm{TVC}=$ Total biaya variabel $(\mathrm{Rp} / \mathrm{tahun})$

\section{Analisis Kelayakan Usaha Ternak Sapi Potong}

Analisis kelayakan usaha, baik untuk pertanian maupun untuk peternakan dapat digunakan dengan rumus sebagai berikut: (Ashari et al. 2013):

$\mathrm{CS}_{\mathrm{i}}=\frac{T C_{i}}{\sum_{i=1}^{n} T C_{i}} \times 100 \%$ atau $\mathrm{CS}_{\mathrm{i}}=\frac{T C_{i}}{T C} \times 100 \%$

dimana:

$\mathrm{CS}_{\mathrm{i}}=$ pangsa biaya input ke- $\mathrm{i}$

$\mathrm{TC}_{\mathrm{i}}$ = biaya input ke-i

$\mathrm{TC}=\sum_{i=1}^{n} T C_{i}=$ total biaya usaha ternak sapi

potong

$$
\sum_{i=1}^{n} C S_{i}=100
$$

Analisis kelayakan usaha dapat digambarkan dari beberapa faktor biaya yang dikeluarkan selama usaha berlangsung/tahun. Menurut Tikupandang et al. (1995) bahwa, nilai pendapatan dapat didefinisikan sebagai selisih antara penerimaan dan total biaya yang telah dikeluarkan dengan rumus sebagai berikut:

$\mathrm{I}=\sum(\mathrm{y}-\mathrm{py})-\sum(\mathrm{Xi}-\mathrm{Pi})$

$\mathrm{I}=$ pendapatan peternak $(\mathrm{Rp})$

$\mathrm{Y}=$ output/hasil sapi potong

$\mathrm{Pxi}=$ harga input ternak sapi potong $(\mathrm{Rp})$

$\mathrm{Pi}=$ output sapi potong $(\mathrm{Rp})$

$\mathrm{Xi}=$ input sapi potong $(1,2,3 \ldots \ldots . \mathrm{n})$

Analisis ekonomi finansial dapat dilakukan dengan menggunakan faktor farsial dan indikator analisis yang dapat dipakai untuk memprediksi usaha untung atau rugi selama satu tahun dengan nilai $\mathrm{B} / \mathrm{C}$ ratio (Benefit Cost Ratio), sesuai dengan pendapat, (Sekarwati 1995). Untuk mengetahui besaran biaya tenaga kerja peternak selama satu tahun dapat dihitung dengan menggunakan rumus: (Rusdiana et al. 2010)

$\mathrm{BTK}=\mathrm{HOK} \times \mathrm{PBR}$

Dimana :

BTK = Biaya tenaga kerja peternak/tahun 
HOK = Curahan tenaga kerja peternak /tahun dan HOK dirumuskan :

$$
\mathrm{HOK}=\frac{\sum \text { jam } \times 360}{8} / \text { tahun }
$$

dimana :

$\sum$ jam $=$ Jumlah jam kerja yang dibutuhkan/peternak /hari

$8=8$ jam kerja/hari (konversi peternak)

$360=$ Konversi ke 1 tahun (360 hari)

\section{HASIL DAN PEMBAHASAN}

\section{Kondisi Umum Wilayah}

Kabupaten Asahan mempunyai luas area sekitar 371.945 ha yang terdiri dari 13 Kecamatan, 176 Desa/Kelurahan definitif setiap Km2, Kabupaten Asahan rata-rata dihuni oleh $\pm 292,16$ ribu jiwa, dengan sebaran yang tidak merata pada setiap Kecamatan dan terakumulasi di daerah pedesaan. Konsentrasi pembangunan perekonomian di Kabupaten Asahan pada tahun 2013 masih tetap mengarah kepada pembangunan pertanian, perkebunan, peternakan dan perikanan, infrastruktur, pendidikan, kesehatan dan bidang perekonomian lainnya. Hal ini ada beberapa pergeseran alih fungsi lahan pertanian serta iklim, cuaca yang kurang mendukung, sehingga hasil yang dicapai tidak maksimal, meskipun demikian pemerintah tetap berusaha melakukan regulasi terhadap pengembangan pertanian dan non pertanian untuk kemajuan perekonomian masyarakatnya., serta berusaha untuk meningkatkan kenaikan gaji pada setiap sektor, jasa-jasa dan buruh lainnya, (Dinas Perkebunan, Pertanian dan Peternakan Kabupaten Asahan 2013).

\section{Tataguna Lahan di Kabupaten Asahan}

Tataguna lahan menunjukkan bahwa, perkebunan sawit, perkebunan karet dan perhutani, yang merupakan bagian terbesar di daerah Kabupaten Asahan, kemudian menyusul kebun campuran, lahan pertanian ladang sawah dan usaha ternak, keadaan ini menggambarkan bahwa daerah Kabupaten Asahan adalah daerah lahan perkebunan. Dengan demikian sebagian besar dari penduduknya mempunyai mata pencaharian sebagai petani, buruh tani, buruh perkebunan, pedagang dan PNS. Disamping itu pula usahatani ternak sapi potong merupakan usaha yang banyak digeluti penduduk setempat. Jumlah dan jenis ternak yang banyak diusahakan adalah ternak sapi, kerbau, kambing, domba, ayam buras, ayam ras, itik.

Luas lahan penggembalaan di Kabupaten Asahan sekitar 15.651,65 ha yang menghasilkan produksi pakan ternak sekitar 96.156,41 ton, produktivitas lahan perkebunan sawit, karet untuk penggembalaan dapat menghasilkan hijauan pakan sekitar 43,76 ton/ha, (Dinas Perkebunan, Pertanian dan Peternakan Kabupaten Asahan 2013).

\section{Karakteristik Peternak Sapi Potong}

Karakteristik peternak sapi potong di Desa Tanah Rakyat Kecamatan Pulobandring Kabupaten Asahan, berdasarkan pengalaman peternak dalam usaha tani ternak rata-rata sekitar 20 tahun dan rata-rata umur peternak sekitar 45,33 tahun, menunjukkan bahwa, angka umur peternak masih dalam kisaran usia yang masih sangat produktif dan cukup matang didukung dengan pengalaman peternak yang cukup lama, sehingga peternak dapat mengelola usaha ternak sapi potong dengan baik. Sedangkan rata-rata pendidikan peternak hampir seluruhnya berpendidikan SD sekitar 53,33\%, SMP sekitar 23,67\% dan SMA sekitar $10 \%$, hal ini menunjukkan bahwa rendahnya tingkat pendidikan peternak rata-rata SD, hal ini tidak mempengaruhi peternak, mengurangi semang usaha tani ternak dan usaha pertanian lainnya.

Menurut Rusdiana et al. (2010) bahwa, sumberdaya manusia baik secara kuantitas maupun kualitas merupakan salah satu faktor utama sebagai penentu keberhasilan usaha tani ternak, sehingga perlu diperhatian agar keberlangsungan tenaga kerja petani dapat dipertahankan dengan baik, sumberdaya manusuia selain alam biasanya terlibat berasal dari dalam keluarga maupun dari luar keluarga petani sendiri. Prioritas peternak untuk melakukan usahanya adalah beternak, buruh perkebunan, dagang dan lainnya, jenis tanaman yang diusahakan adalah: kelapa sawit, jangung, kacang tanah, ubi kayu, ubi jalar, sayuran dan lainnya, sedangkan untuk jenis ternak yang diusahakan adalah, sapi potong, kambing, domba, ayam dan itik dan lainnya.

Hampir semua masyarakat sekitar di Desa Tanah Rakyat mengolah lahan perkebunan milik swasta dan mengolah lahan 
pertanian milik sendiri, selain usaha bertani, buruh perkebunan juga melakukan usaha dagang, ternak sapi potong yang dipelihara sebagian besar milik sendiri dan sebagian kecil milik orang lain, Hamparan lahan kosong (tegalan), lahan perkebunan kelapa sawit dan perkebunan karet terdapat rumput dan sisa limbah pertanian, cukup berpengaruh untuk kebutuhan ternak sapi potong yang dipelihara oleh peternak di sekitar lingkungan perkebunan, diharapkan peternak sapi potong dapat berkembang biak dan pertumbuhannya lebih optimal.

\section{Penguasaan Ternak Sapi Potong di Petani}

Hasil survey lapang pada peternak sapi potong bahwa di Desa Tanah Rakyat Kabupaten Pulobandring Kabupaten Asahan, jumlah ternak sapi potong yang dipelihara oleh peternak dari tahun ke tahun relatif bertambah, tahun 2014 jumlah ternak sapi potong yang dipelihara sekitar \pm 1.260 . ekor dan tahun 2015 ternak sapi potong sekitar \pm 1.500 ekor. Jenis ternak sapi potong yang dipelihara adalah sapi Bali, sapi PO, sapi Aceh, Jabres dan sapi lainnya. Rataan penguasaan ternak sapi potong pada peternak terlihat pada Tabel.1.

Pada Tabel 1. menunjukkan bahwa, ternak sapi potong secara persentase status sapi potong betina dewasa menduduki posisi yang cukup tertinggi, dengan pemeliharaan rata-rata sekitar 3,4 ekor/peternak atau sekitar 33,77\%, betina induk untuk menghasilkan keturunan anaknnya dan sebagian lagi untuk pembesaran jantan baik, dewasa maupun muda, penggemalaan dilakukan pada jam 8 pagi dan dikandangkan pada jaml 5 sore. Luas lahan perkebunan kelapa sawit sekitar \pm 750 ha dan perkebunan karet sekitar \pm 620 ha, milik suwata dan sebagian kecil perkebunan kelapa sawit milik rakyat 20-30 ha, disekitar lahan perkebunan ternak sapi potong digembalakan sehingga, ternak sapi potong sanget berpeluang untuk dikembangkan, baik dengan cara budidaya dan pembesaran jantan.

Pada skala pemilikan betina induk ratarata 3,4 ekor, diperkirakan seekor induk dapat menghasilkan anak paling sedikit sekitar $80 \% /$ kelahiran, sehingga jumah ternak sapi di peternak akan bertambah rata-rata sekitar 2,6 ekor/tahun/peternak. Dengan demikian jumlah dan produksi ternak sapi potong yang dipelihara peternak dapat menentukan besarnya peran peternak dalam usaha pengembangan ternak sapi potong dilahan perkebunan kelapa sawit dan perekbunan karet Berdasarkan data dan informasi dari peternak bahwa, ternak sapi potong yang dipelihara kelahirannya banyak di dominasi oleh kelahiran anak betina sekitar $15,73 \%$ dan anak jantan sekitar $12,45 \%$, untuk itu perlu dipertahankan manajemen pakan dan pemeliharaan yang baik, agar anak betina dapat berkembang, dijadikan sebagai bahan induk untuk tahun berikutnya.

Faktor pakan dapat menentukan perkembangan populasi ternak sapi potong melalui betina induk menghasilkan anak, disamping itu pula pakan banyak tersedia di lahan perkebunan kelapa sawit dan karet, namun demikian peranan ternak sapi potong betina induk dewasa dan jantan dewasa merupakan usaha peternak dengan kontribusi pendapatan tertinggi, walaupun kenyataannya belum menjadi pusat perhatian peternak. Hal ini semakin memperkuat bukti bahwa, komponen penentu berkembangnya ternak sapi potong di peternak, dikarenakan masih

Tabel 1. Rataan penguasaan ternak sapi potong di peternak 2015

\begin{tabular}{lccc}
\hline \multicolumn{1}{c}{ Uraian } & \multicolumn{3}{c}{$\begin{array}{c}\text { Peternakan sapi potong } \\
\text { di Desa Tanah Rakyat n-30 }\end{array}$} \\
\hline Betina dewasa & Jumlah /ekor & Rata-rata/ekor & Persentase \\
Betina muda & 102 & 3,4 & 33.77 \\
Betina anak & 57 & 1.9 & 18.69 \\
Jantan dewasa & 48 & 1.6 & 15.73 \\
Jantan muda & 32 & 1.1 & 10.49 \\
Jantan anak & 28 & 0.9 & 9.18 \\
Jumlah & 38 & 1.3 & 12.45 \\
Sumbr data dar peta & 6.8 & 100 \\
\hline
\end{tabular}

Sumber data dari peternak di olah (2015) 
S.Rusdiana, R. Hutasoit dan J. Sirait : Analisis Ekonomi Usaha Sapi Potong ...

Tabel.2. Rata-rata waktu kerja peternak sapi potong/tahun

\begin{tabular}{llrrrrrr}
\hline \multirow{2}{*}{ Jenis pekerjaan } & \multicolumn{7}{c}{ Desa Tanah Rakyat n-15 } \\
\cline { 2 - 8 } & \multicolumn{1}{c}{ Jam/ } & $\%$ & rata-rata & thn/hari \\
n-30 & & (360) & $\begin{array}{c}\text { 8 hok 1 } \\
\text { jam }\end{array}$ & $\begin{array}{c}\text { Rp./thn } \\
(20.000)\end{array}$ \\
\hline Mengambil hijauan & 0 & 0 & 0 & 0 & 0 & 0 \\
Digembalakan & 198 & 86.84 & 6.6 & $2.376 / 8$ & 297 & 5.940 .000 \\
Perawatan ternak & 30 & 13.16 & 1.0 & $360 / 8$ & 45 & 900.000 \\
Jumlah & 228 & 100 & 7,6 & $2.736 / 8$ & 342 & 6.840 .000 \\
\hline
\end{tabular}

Keterangan 8 jam kerja dihitung 1 (HOK) Rp.20.000,-

banyaknya hijauan pakan yang tumbuh disembarang tempat, diantaranya di lahan kosong (tegalan), perkebunan kelapa sawit, perkebunan karet dan limbah pertanian, semuanya dapat dimanfaatkan sebagai pakan ternak dan sebagai tempat penggembalaan.

\section{Penyerapan Tenaga Kerja Peternak}

Hasil survey menunjukan bahwa tenaga kerja keluarga peternak, untuk usaha ternak sapi potong dengan cara penggembalaan dapat diasumsikan selama satu tahun (360 hari kerja). Penggunaan waktu kerja peternak untuk menggembala sapi potong dengan cara bergilir setiap harinya, sesuai dengan hasil musyawarah peternak. Jumlah dan waktu yang digunakan untuk mengerjakan usahanya tetap, akan melibatkan tenaga kerja keluarga, (Nandang et al. 1996). Curahan tenaga kerja selama proses produksi diawali dengan kegiatan persiapan sampai pemeliharaan hingga akhir pascapanen, (Dewi et al. 2007).

Tenaga kerja peternak di Desa Tanah Rakyat waktu yang digunakan untuk usaha pemeliharaan ternak sapi potong dengan cara menggembalakan tidak meningkat, dengan meningkatnya jumlah ternak sapi potong yang dipelihara. Ternak sapi potong relatif sama dan nampak bahwa, tenaga kerja peternak dihitung berdasarkan alokasi waktu yang digunakan oleh masing-masing peternak, waktu yang digunakan sekitar 8 jam/hari kerja, dihitung 1 (satu) Hok, dengan perhitungan biaya sebesar Rp.20.000/hari/peternak terlihat pada Tabel.2.

Tabel.2. Menunjukkan bahwa, hasil perhitungan tenaga kerja peternak (Rp/Hok/tahun) pada peternak sapi potong di Desa Tanah Rakyat dengan cara digembalakan dilahan perkebunan kelapa sawit dan karet sekitar Rp.5.940.000 atau (297 Hok/tahun) dan perawatan ternak sekitar Rp.900.000/tahun atau (45 Hok/tahun), jumlah biaya untuk tenaga kerja peternak sekitar Rp.6.840.000/tahun atau (342/Hok/tahun). Kegiatan dalam tatalaksana usaha pemeliharaan ternak sapi potong memerlukan kualitas dan intensitas kerja peternak, menuntut tenaga kerja yang cukup banyak waktu yang digunakan untuk mengawasi ternak pada saat digembalakan. Kebutuhan tenaga kerja dapat dipenuhi oleh peternak dan keluarganya, upah tenaga kerja petani ternak sapi potog dihitung sekitar Rp.15.000-20.000/hari, dan waktu kerja 8 jam/hari, dihitung berdasarkan 1 Hok kerja/hari.

Menurut Rusastra et al. (2005); Ashari et al. (2013) bahwa, upah tenaga kerja pria petani untuk menggarap lahan pertanian dalam sehari dan dengan upah mengalami peningkatan antara sekitar Rp.20.000-25.000/hari kerja, sementara upah tenaga kerja petani wanita, dalam periode yang sama mengalami peningkatan dari Rp.15.000-20.000/hari kerja. Ketersediaan tenaga buruh tani sebenarnya cukup memungkinakan, apabila tenaga kerja keluarga petani dipedesaan tidak berimigrasi ke luar daerah, maka tenaga kerja petani di pedesaan cukup banyak. Curahan tenaga kerja yang digunakan oleh peternak sapi potong tidak berpengaruh dalam aktivitas usaha sampingan.

Petani ternak tersebut merasa untung, karena petani ternak mempunyai alasan yaitu mudah mencari rumput, mudah menjual hasil ternak, mudah memelihara ternak dan kotoran kandang bermanfaat untuk kesuburan tanaman.

Rotasi Lahan Penggembalaan Sapi Potong

Peternak sapi potong di Desa Tanah Rakyat dalam melakukan aktivitas usaha menggembalakan ternaknya di lahan perkebunan kelapa sawit dan perkebunan karet, penggembalaan dilakukan dengan cara rotasi atau perputaran penggembalaan. Peternak memindahkan ternaknya di lahan 
penggembalaan berikutnya, kemudian lahan yang ditinggalkan dibiarkan selama 1-3 bulan. Agar rerumputan dapat tumbuh kembali, dapat digunakan lagi sebagai lahan penggembalaan ternak sapi potong untuk berikutnya. Peternak dalam melakukan rotasi atau perputaran lahan penggembalaan sudah terbiasa dilakukan setiap tahun, sebelum ternak digembalakan peternak mengontrol lahan yang akan digunakan sebagai tempat penggembalaan ternaknya.

Peternak menggiring ternak sapi potong ke tempat lahan yang masih banyak hijauan pakan atau rerumputan yang tumbuh disekitar lahan perkebuanan sawit dan karet, perkiraan luas lahan perekebunan kelapa sawit dan karet yang digunakan sebagai lahan penggembalaan ternak sapi potong milik rakyat sekitar 500-700 ha, dan perkiraan jumlah ternak sapi potong sekitar 500-1.500 ekor yang memanfaatkan lahan tersebut. Sedangkan lahan yang digunakan sebagai tempat penggembalaan setiap harinya kira-kira sekitar 5-10 ha. Ternak sapi potong bila merumput selalu berkoloni rata-rata sekitar 5-10 ekor/ kelompok dalam satu kawasan lahan penggembalaan, pengawasan ternak dilakukan setiap saat, sehingga ternak yang sedang merumput dapat terkontrol dengan baik oleh pemilik ternak.

\section{Analisis Usaha Ternak Sapi Potong}

Menurut Amik et al. (2006) bahwa, analisis ekonomi berupa analisis finansial untuk mengetahui tingkat keuntungan yang diperoleh petani, penggunaan tenaga kerja dan biaya yang dikeluarkan di samping bibit, sedangkan untuk mengetahui pendapatan selama satu tahun yang diterima oleh petani pada saat petani panen atau menjual hasil usahanya. Hasil survey di lapangan menunjukkan, bahwa petani ternak sapi potong dengan pemeliharaan selama satu tahun, pendapatan kotor dan pendapatan bersih secara ekonomi dapat dihitung berdasarkan jumlah pendapatan kotor dikurangi dengan biaya-biaya produksi selama usaha berlangsung, pendapatan bersih yang diterima oleh peternak secara rill sudah bersih dari biaya-biaya lainnya.

Untuk mendukung peternak sapi potong agar pendapatannya lebih layak, maka peternak harus melakukan usahanya harus ini inti, tidak melakukan dengan usaha lainnya. Dibutuhkan juga kapasitas daya tampung ternak sapi potong yang akan dijual, sehingga harga sapi potong di peternak lebh tinggi. Disamping itu pula peternak dalam melakukan aktivitas penjualan ternaknya sapi potong mendapat posisi nilai jual yang sesuai dengan harga pasar, sesuai dengan harapan para peternak, berkaitan dengan penggunaan beberapa faktor biaya yang dikeluarkan selama usaha berlangsung, sehingga peternak dapat mengevisiensikan biaya-biaya produksi, diantaranya untuk biaya tenaga kerja, bibit, pakan, pembuatan kandang dan obat-obatan.

Rata-rata peternak dalam pemeliharaan ternak sapi potong sekitar 6,8 ekor/peternak, betina dewasa, muda danak anak, jantan dewasa, muda dan anak. Penerimaan tunai hanya terkonsentrasi pada penjualan ternak sapi potong per tahun dan tidak dialokasikan penjualan pupuk kandang, karena semuanya dimanfaatkan untuk pupuk di lahan peternak. Hasil penelitian yang telah dilakukan oleh Rusdiana et al. (2010), menunjukkan bahwa semakin tinggi skala pemeliharaan ternak sapi potong produktif, maka indek efisiensi ekonomi akan semakin tinggi keuntungan yang diperoleh peternak. Menurut Gittinger (1989) bahwa, analisis perkiraan ekonomi adalah hasil usaha pada umumnya digunakan untuk mengevaluasi kegiatan usaha selama jangka waktu tertentu dapat dihitung berdsarakan waktu satu tahun atau periode tertentu.

Secara teknis usaha ternak sapi potong dapat dianalisis secara ekonomi untung dan rugi, apabila ternak yang dipelihara menghasilkan anak, dan apabila ternak yang dipelihara selama jangka waktu tertentu tidak menghasilkan maka perhitungan peternak rugi, artinya ternak tidak menghasilkan keuntungan, biasanya peternak menilai untung dengan bertambahnya jumlah anak sekelahiran. Ternak sapi potong biasanya melahirkan anak dalam jangka waktu 1,5 tahun, 1 kali melahirkan, sehngga nilai pertambahan ekonomi peternak akan terlihat. Untuk melihat koefisien ternak sapi potong secara teknis dapat diukur melalui beberapa data yang perlukan sebagai berikut:

\section{Faktor Ekonomi}

Harga sapi potong untuk bibit (rata-rata umur 12 bulan) : Rp.7.570.000

Tenaga kerja keluarga peternak 8 jam 1 Hok/hari/peternak : Rp.20.000.

Penyusutan kandang /5 tahun

$$
\text { : Rp.650.000 }
$$


Peralatan kandang/tahun

: Rp.200.000

Harga jual sapi potong induk/ekor : Rp.9.855.000

Harga jual sapi potong betina muda : Rp.7.250.000

Harga jual sapi potong jantan muda

$$
\text { : Rp.8.450.000 }
$$

Biaya pakan diasumsikan ke dalam biaya tenaga kerja petani: Rp.6.450.000

\section{Faktor Teknis}

Sapi potong untuk bibit umur awal dpelihara sekiar umur : 12 bulan

Jumlah ternak sapi potong awal dipelihara : 4 ekor betina produktif

Lama pemeliharaan dihitung berdasakan usaha/tahun : 1-2 tahun

Kematian selama pemeliharaan dinilai $:(0 \%)$

Analisis ekonomi usaha ternak sapi potong pada peternak di Desa Tanah Rakyat Kecamatan Pulobandring Kabupaten Asahan, dengan skala pemeliharaan 4 ekor betina induk, sebagai bibit awal. Pemeliharaan untuk proses produksi menghasilkan anak yang dapat dipelihara sampai umur anak mencapai sekitar 8-12 bulan, dengan nilai jual harga ternak sapi potong jantan muda sekitar Rp.8.450.000/ekor, dan nilai jual harga ternak sapi potong betina muda sekitar Rp.7.250.000/ekor menurut peternak sesuai dengan keinginannya, analisis ekonomi usaha sapi potong, terlihat pada Tabel.3.

Tabel.3. Menunjukkan bahwa biaya produksi untuk pembelian pakan dapat dimasukkan ke dalam biaya tenaga kerja peternak sekitar Rp.6.840.000/tahun, peternak melakukan usaha pemeliharaan sapi potong dengan cara digembalakan di lahan perkebunan kelapa sawit dan di karet, jadi biaya yang banyak dikeluarkan untuk biaya tenaga kerja menggembalakan, pendapatan bersih sekitar Rp.3.185.000/peternak/tahun dengan nilai B/C ratio 1,2 .

Tabel.3. Rataan anallisis ekonomi usaha sapi potong di peternak 2015

\begin{tabular}{|c|c|c|c|}
\hline Uraian & Volume & $\begin{array}{l}\text { Rata-rata/ } \\
\text { harga (Rp) }\end{array}$ & $\begin{array}{c}\text { Jumlah } \\
\text { ( Rp) }\end{array}$ \\
\hline \multicolumn{4}{|l|}{ A. Biaya Investasi dan Penyusutan } \\
\hline - pembelian bibit sapi potong & 4 ekor & 7.570 .000 & 30.280 .000 \\
\hline - kandang sapi potong (unit) & 1 & 3.250 .000 & - \\
\hline - penyusutan kandang /5 tahun & & & 650.000 \\
\hline - peralatan kandang (paket)/tahun & 1 & 500.000 & 200.000 \\
\hline Jumlah & & & 31.130 .000 \\
\hline \multicolumn{4}{|l|}{ B. Biaya variabel } \\
\hline - tenaga kerja peternak (Hok)/tahun & 342 Hok & $20 . .000$ & 6.840 .000 \\
\hline - pakan konsentrat $(\mathrm{kg}) /$ tahun & - & - & - \\
\hline - pakan hijauan (kg)/tahun & - & - & - \\
\hline - obat-obatan (paket)/tahun & 1 paket & 100.000 & 100.000 \\
\hline Jumlah & & & 6.940 .000 \\
\hline Total (A + B) & & & 38.070 .000 \\
\hline \multicolumn{4}{|l|}{ C. Pendapatan } \\
\hline -penjualan betina dewasa (ekor) & 1,0 ekor & 9.855 .000 & 9.855 .000 \\
\hline -penjualan betina muda (ekor) & 2,0 ekor & 7. 250.000 & 14.500 .000 \\
\hline -penjualan jantan muda ( ekor) & 2,0 ekor & 8.450 .000 & 16.900.000 \\
\hline Jumlah & & & 41.255 .000 \\
\hline - Pendapatan kotor & & & 41.255 .000 \\
\hline - Pendapatan bersih/tahun & & & 3.185 .000 \\
\hline - Pendapatan bersih/bulan & & & 265.416 \\
\hline$-B / C$ & & & 1,2 \\
\hline
\end{tabular}

Keterangan: induk sapi potong masih dipelihara peternak, untuk investasi tahun berikutnya. 


\section{KESIMPULAN DAN SARAN}

\section{Kesimpulan}

Tingkat keberhasilan peternak sapi potong di Desa Tanah Rakyat Kecamatan Pulobandring Kabupaten Asahan Propinsi Sumatera Utara cukup tinggi, rata-rata waktu kerja peternak yang digunaan untuk usaha pemeliharaan ternak sapi potong menggembalakan dilahan perkebunan kelapa sawit dan karet sekitar Rp.5.940.000 atau (297 Hok/tahun) dan perawatan ternak sekitar Rp.900.000/tahun atau (45 Hok/tahun), jumlah biaya untuk tenaga kerja peternak sekitar Rp.6.840.000/tahun atau (342/Hok/tahun).

Pendapatan bersih dari hasil usaha pemeliharaan ternak sapi potong dengan cara digembalakan di lahan perkebunan kelapa sawit dan dilahan perkebunan karet, keuntungan bersih sekitar Rp.3.185.000/tahun dengan B/C ratio 1.2. Untuk itu peternak segera didorong ke arah usaha yang bersifat komersial, agar ternak sapi potong yang dipelihara oleh peternak bertambah dan mendapat nilai jual yang lebih tinggi dari segi harga pasar sapi potong.

\section{Saran}

Diharapkan dukungan pemerintah daerah dan pihak pengembang perkebunan dapat mendukung kepada peternak sapi potong, karena sebagian peternak merupakan peternak kecil dengan tingkat keterampilan yang rendah, sehingga pemerintah melalui Dinas terkait menyiapkan tenaga ahli sebagai pendaping di lapang yang dapat membimbing peternak sapi potong di Desa Tanah rakyat.

Diharapkan ternak sapi potong yang merupakan salah satu satu komoditas utama bagi peternak di Desa Tanah rakyat dapat mempertahankan ternaknya, karena ternak sapi potong bagi peternak sebagai fungsi pendapatan utama, tabungan untuk kebutuhan anak sekolah dan lainnya. Mengingat sifat dan reproduksi sapi potong sangat lama sekitar satu tahun, peternak masih berusaha memelihara ternaknya.

\section{DAFTAR PUSTAKA}

Amik Krismawati dan M,A. Firmansyah. 2006. Kajian teknologi usahatani jagung dilahan kering Kalimantan Selatan. Pusat Penelitian dan Pengembangan Sosial
Ekonomi Pertanian, Badan Litbang

Pertanian. Jurnal Pengkajian dan Pengembangan Teknologi Pertanian Vol.8 No.1 Maret 2006.

Atmakusuma, J, Harmini dan Ratna W. 2011.Mungkinkah swasembada daging terwujud. Jurnal Risalah Kebijakan Pertanian dan Lingkungan, Departemen Agribisnis, Jurnal Ekonomi Pertanian Fakultas Ekonomi dan Manajemen IPB Bogor 16680, juniaratmakusuma@gmail.com.VVol.1 No. 2, agustus 2014: 105-109 issn: 2355-6226 hal.105-109

Ashari, Ening Ariningsih, Yana Supriyatna, Cut.R. Adawiyah dan Sri Suharyono. 2013. Kajian Efektivitas Sistem Resi Gudang dalam Stabilisasi Pendapatan Petani. Laporan Kegiatan Kajian Isu-Isu Aktual Kebijakan Pembangunan Pertanian Pusat Sosial Ekonomi dan Kebijakan Pertanian Badan Penelitian dan Pengembangan Pertanian, Kementerian Pertanian, Desember 2013, hal, 1-115.

Demitria.D., Harianto, Sjafri.M., dan Nunung. 2006. Peran pembangunan sumberdaya manusia dalam peningkatan pendapatan rumah tangga petani di Daerah Istimewa Yogyakarta. Forum Pascasarjana. IPB. Vol.33. No.3. Juli 2010. hal. 155-164.

Dewi.S., Alam dan Haris. 2007. Analisis titik impas dan sensitivitas terhadap kelayakan finansial usahatani padi sawah. Balai Besar Pengkajian dan Pengembangan Teknologi Pertanian Bogor, Jurnal Pengkajian dan Pengembangan Teknologi Pertanian Vol. 10 No. 2, Juli 2007, hal, 119-125

Direktorat Jenderal Peternakan dan Kesehatan Hewan. 2013. Kementerian Pertanian Republik Indonesia Jakarta Selatan. http://Ditjennak@pertanian.go.id.

Dinas Pertanian dan Peternakan Kabupaten Asahan 2013. Statistik Kabupaten Asahan Dalam Angka sementara. Dinas 


\section{S.Rusdiana, R. Hutasoit dan J. Sirait : Analisis Ekonomi Usaha Sapi Potong ...}

Penyuluh Pertanian dan Peternakan Kabupaten Asahan. 2011

Hadi, P.U. dan N. Ilham. 2002. Problem dan prospek pengembangan usaha pembibitan sapi potong di Indonesia. J. Litbang, Pertanian. 21 (4): 148-157.

Kusnadi,U., B.Setiadi dan E. Juarini. 2006. Analisis potensi wilayah peternakan di pulau Sumatera. Prosiding Seminar Nasional Peternakan, Balai Pengkajian Teknologi Pertanian Sumatera Barat, Kerjasama, Dinas Peternakan Provinsi Sumatera Barat, Balai Besar Pengkajian Pengembangan Teknologi Pertanian, Badan Penelitian dan Pengembangan Pertanian, Padang 11-12 September 2006. hal. 32-41.

Nandang S. U.Kusnadi dan D. Sugandi. 1996. Penyerapan Tenaga Kerja Keluarga Petni Ternak Oleh Usaha Penggemukan Sapi Potong Peranakan Ongole (Po) Sistem Keraman. Proseding Teтu Ilmiah. Aplikasi Hasil Penelitian untuk Industri Peternakan Rakyat. Puslitbangnak Bogor 8-11 januari 1996, hal. 149-157.

Rusastra, I W., K.M. Noekman, Supriyati, E. Suryani, M. Suryadi dan R. Elizabeth. 2005. Analisis

Ekonomi
Ketenagakerjaan Sektor Pertanian dan Pedesaan di Indonesia. Laporan Hasil Penelitian. Pusat Sosial Ekonomi dan Kebijakan Pertanian, Kementerian Pertanian, Bogor, hal,1-108.

Rusdiana.S., dan A.Bamualim. 2009. Memacu peningkatan populasi sapi potong dalam upaya peningkatan produksi daging. Prosing Seminar Nasional Balai Besar Pengkajian dan Pengembangan Teknologi Pertanian, Bogor 15-16 Oktober 2009, hal. 169-177.

Rusdiana.S. B. Wibowo dam L. Praharani. 2010. Penyerapan sumberdaya manusia dalam analisis fungsi usaha penggemukan sapi potong rakyat di pedesaan. Seminar Nasional Teknologi Teternakan dan Veteriner Bogor, 3-4 Agustus 2010, hal, 453-460.

Tikupandang.A., A. Prabowo dan D. Sugandi. 1995. Aspek tenaga kerja kelurga dalam sistem usahatani ternak terpadu di daerah transmigran Sulawesi Selatan. Prosiding Seminar Nasional Sains dan Teknologi Peternakan Pengelolaan dan Komunikasi Hasil-hasil Penelitian Balai Penelitian Ternak Ciawi-Bogor, hal. 539-545. 